\title{
The Interactions of Herbal Compounds with Human Organic Anion/Cation Transporters
}

\author{
Xiaoxi Lu ${ }^{1}$, Ting Chan ${ }^{1}$, Chenghao $\mathrm{Xu}^{1}$, Wee Vean $\mathrm{Ng}^{1}$, Ling $\mathrm{Zhu}^{2}$ and Fanfan Zhou ${ }^{2 *}$ \\ ${ }^{1}$ Faculty of Pharmacy, The University of Sydney, NSW, Australia \\ ${ }^{2}$ Retinal Therapeutics Research Group, Save Sight Institute, The University of Sydney, Sydney, NSW, Australia
}

\begin{abstract}
The Solute Carrier transporters (SLCs) are a superfamily of membrane proteins responsible for cellular influx of various molecules. The Organic anion transporting polypeptides (OATPs), Organic anion transporters (OATs) and Organic cation transporters (OCTs) are essential SLC subfamilies that largely impact on drug performance. These Organic anion/cation transporters are widely expressed in epithelium throughout the body, where they play essential roles in cellular uptake of many endogenous substances like hormones and a wide range of exogenous molecules including clinically important drugs such as statins, anti-cancer agents and antibiotics. Herbal medicines that derived from plants, fruits and vegetables have been long presumed to be safe by the general public. The growing use of herbal products together with other agents has raised many concerns due to unexpected adverse effects. Drugdrug/herb interactions through SLC transporters often result in unsatisfied therapeutic outcomes and/or unexpected toxicities. This review will give an update on the interactions of herbal compounds with human Organic anion/cation transporters in order to form the basis of better and safer drug therapies.
\end{abstract}

Keywords: Solute carrier transporters; Organic anion transporters; Organic cation transporters; Organic anion transporting peptides

\section{Abbreviations}

OATs: Organic Anion Transporters; OCTs: Organic Cation Transporters; OATPs: Organic Anion Transporting Peptides; SLCs: Solute Carrier Transporters

\section{Introduction}

The Solute carrier transporters (SLCs) are important membrane proteins responsible for cellular influx of a wide range of molecules. They have been widely studied by researchers especially in the renal and hepatic physiology field for a long period of time. The Organic anion transporting polypeptides (OATPs) encoded by SLCO gene family, Organic anion transporters (OATs) and Organic cation transporters (OCTs) falling into the SLC21 gene family are the most important SLC subfamilies relevant to drug performance.

OATs, OCTs and OATPs widely distribute throughout the epithelium of human key organs including the kidney, liver and intestine, where they facilitate the access of many endogenous and exogenous substances to specific tissues (Table 1) [1-3]. Therefore, these transporters are broadly recognized to be clinically important in the absorption, distribution and elimination of drugs [4]. And pharmaceutical inventors are required by the regulatory authorities to evaluate the potentials of drug-drug interactions through the essential Organic anion/cation transporters in the pre-clinical phase of drug development.

Herbal medicines derived from plants, fruits and vegetables are widely adopted in the world especially in many Asian countries. They have been considered to be safe by the general public. However, there are reports of unexpected adverse events with the co-administration of herbal medicines and pharmaceutical agents. Arising knowledge in the recent decade indicated that many herbal compounds are modulators of OATs, OATPs and OCTs, which significantly impact on cellular uptake of other transporter substrates. With an increasing use of herbal medicines, it is plausible that therapeutic toxicities likely occur due to drug substrates competing for specific transporters with herbal compounds. Therefore, knowledge about the interactions of natural compounds on the Organic anion/cation transporters is essential to prevent alterations of the performance of clinically important drugs [5]. In this review, tissue distribution, substrate specificity, clinical significance and interactions with herbal compounds are described for those well characterized OAT, OCT and OATP isomembers.

\section{Organic Anion Transporters}

OATs are known to mediate uptake of water-soluble, negatively charged organic molecules with low molecular weight such as steroid hormones and their conjugates, biogenic amines, numerous drugs and toxins [6,7]. So far, there are nine human OAT isoforms identified with OAT1, OAT2, OAT3 and OAT4 better characterized $[1,6]$.

\section{Tissue distribution}

OAT1 was first discovered as a para-aminohippurate $(P A H)$ transporter in 1997 [7-9], which is abundantly expressed at the basolateral membrane of renal proximal tubular cells [10-15]. OAT2 was found to be predominantly expressed in the liver and also located at the blood-facing membrane of renal tubular cells $[16,17]$. OAT3 is widely expressed in the kidney, brain and liver [18]. OAT4 distributes at the apical membrane of renal proximal tubular cells and the basolateral membrane of syncytiotrophoblasts in the placenta [12,19-22]. OAT5 and OAT7 are found in human liver, while OAT10 distributes at the apical membrane of renal proximal tubules cells [23-25].

*Corresponding author: Fanfan Zhou, Faculty of Pharmacy, The University of Sydney, Sydney, NSW, 2006, Australia, Tel: 61-2-9351-7461; Fax: 61-2-93514391; E-mail: fanfan.zhou@sydney.edu.au

Received October 28, 2014; Accepted November 20, 2014; Published November 27, 2014

Citation: Lu X, Chan T, Xu C, Ng WV, Zhu L (2014) The Interactions of Herbal Compounds with Human Organic Anion/Cation Transporters. J Pharmacogenomics Pharmacoproteomics 5: 142. doi:10.4172/2153-0645.1000142

Copyright: ( $) 2014 \mathrm{Lu} \mathrm{X}$, et al. This is an open-access article distributed under the terms of the Creative Commons Attribution License, which permits unrestricted use, distribution, and reproduction in any medium, provided the original author and source are credited. 
Citation: Lu X, Chan T, Xu C, Ng WV, Zhu L (2014) The Interactions of Herbal Compounds with Human Organic Anion/Cation Transporters. J Pharmacogenomics Pharmacoproteomics 5: 142. doi:10.4172/2153-0645.1000142

Page 2 of 8

\begin{tabular}{|c|c|c|c|c|c|}
\hline & Liver & Intestine & Kidney & Blood Brain Barrier & Placenta \\
\hline Apical membrane & & $\begin{array}{c}\text { OATP1A2 OATP2B1 } \\
\text { OCT1 } \\
\text { OCTN1 } \\
\text { OCTN2 }\end{array}$ & $\begin{array}{l}\text { OATP1A2 } \\
\text { OAT4 } \\
\text { OCTN1 } \\
\text { OCTN2 }\end{array}$ & $\begin{array}{l}\text { OATP1A2 } \\
\text { OATP2B1 }\end{array}$ & OATP4A1 \\
\hline Basolateral membrane & $\begin{array}{c}\text { OATP1B1 OATP1B3 } \\
\text { OATP2B1 OAT2 } \\
\text { OCT1 } \\
\text { OCT3 }\end{array}$ & & $\begin{array}{c}\text { OATP4C1 } \\
\text { OAT1 } \\
\text { OAT2 } \\
\text { OAT3 } \\
\text { OCT2 } \\
\text { OCT3 }\end{array}$ & & $\begin{array}{c}\text { OATP2B1 } \\
\text { OAT4 }\end{array}$ \\
\hline
\end{tabular}

Table 1: Localization of the major SLC transporters in human epithelium [1-3].

\section{Substrate specificity}

OATs are responsible for the transport of lower molecular mass molecules compared to OATPs. Their endogenous substrates include a-ketoglutarate, prostaglandins and cyclic guanosine monophosphates $[9,26,27]$. Additionally, they are capable of mediating the uptake of therapeutic drugs such as NSAIDs, antivirals and anti-cancer agents. For example, OAT3 is responsible for the uptake of cimetidine, a histamine $\mathrm{H} 2$-receptor antagonist widely used in treating heartburn and peptic ulcers, as well as that of methotrexate, an anti-metabolite and anti-folate drug frequently used to manage cancers and autoimmune diseases [28].

\section{Clinically significance}

In vitro and in vivo studies have shown that OAT1 and OAT3 are primarily responsible for uptake of common drug substrates from blood to renal proximal tubular cells [29]. Due to their broad substrate specificities, OAT1 and OAT3 play essential roles in renal excretion of many drugs and toxins. For instance, the drug-drug interaction between probenecid and methotrexate was discovered in 1970s [30,31], which was later identified as probenecid-induced down-regulation of methotrexate transport via OAT1 and OAT3 [32].

\section{The interactions of herbal compounds with OATs}

Several previous studies of others and us have demonstrated that various natural compounds are potent inhibitors or substrates of OATs (Table 2). OAT1 and OAT3 are the two well-known OAT isoforms mainly distributed at the blood-facing basolateral membrane of the renal proximal tubular cells, where they facilitate the renal excretion of a wide range of substances; while OAT4 is one of the key players of renal re-absorption present at the luminal-facing apical membrane of the proximal tubule. The transport activities of these three OAT isoforms are of the most interests to researchers with many studies extensively evaluated their roles in drug performance.

Our laboratory conducted a series of studies to explore the interactions of clinically important natural compounds with thirteen essential SLC transporters that are best characterized so far. These transporters broadly cover the ranges of OATs, OATPs and OCTs/ OCTNs and greatly influence the pharmacokinetic performance of many pharmaceutical agents. In our studies, we identified that ursolic acid, the active component of Punica granatum Linnaeus (pomegranate), was found to inhibit OAT3 transport activity [19]. Due to the anti-oxidant property and anti-diabetic potentials of pomegranate, products derived from this fruit are very popular worldwidely, the increasing use of which might significantly impact on therapies involved with drugs that are substrate of OAT3. In addition, wogonin and baicalein, the two major active ingredients of Scutellaria baicalensis were shown to markedly inhibit OAT1-, OAT3- and OAT4mediated substrate uptake [33]. Since these compounds commonly used in treating inflammation, hypertension and many infections [34], such finding is also clinically significant.

Wang et al. revealed that Lithospermic acid (LSA), salvianolic acid A (SAA) and rosmarinic acid (RMA) that are enriched in commercial Danshen preparations, are potent inhibitors of OATs. In details, RMA was shown to significantly down-regulate the transport activity of OAT1 and OAT3; while LSA and SAA was found to potently interact with OAT3 [35]. Since Danshen has been long used in cardiovascular treatment, there might be herb-drug interactions in situations of co-administration of Danshen with clinical agents known to be substrates of these OATs. In another study of this group, the authors demonstrated that rhein, the main component of Rheum sp. in treating osteoarthritis and diabetic nephropathy, selectively inhibit the uptake of OAT1 and OAT3; while it has much less impairment on OAT4mediated substrate influx [36]. Gallic acid, a major component of many herbal products has also been demonstrated to be a potent inhibitor of hOAT1 and hOAT3, the plasma concentration of which is sufficient to cause drug-herb interactions [37].

Grapefruit juice has long been implicated in drug-herb interactions of therapies. The main constituents of grapefruie juice are flavonoids, five of which including morin, silybin, naringin, naringenin and quercetin have been explored for their interactions with OAT1 and OAT3 [38]. Morin and silybin are potent inhibitors of OAT1; while all the five flavonoids tested in this study has less pronounced interactions with OAT3.

Nephrotoxicity related incidents have been reported following consumptions of common herbal products made from Aristolochiaceae [39-41]. Aristolochic acids (mainly AA-I and AA-II) contained in these herbal medicines were later found to be associated with these adverse effects. Both AA-I and AA-II potently inhibit the substrate uptake mediated through OAT1 and OAT3 as well as moderately impact on that of OAT4 [42].

Interestingly, the major metabolites and/or derivatives of various natural compounds were also reported to be inhibitors or substrates of OATs. For instance, 3-monoglucuronyl-glycyrrhetinic acid (3MGA), one of the major metabolites of glycyrrhizin (GL), has been demonstrated to be a substrate of OAT1 and OAT3 [43]. And GL is the main component of the root of glycyrrhiz widely used in treating chronic hepatitis C and gastric ulcers in Japan and Europe [44,45]. It is noteworthy that steviol (the aglycone metabolite of the noncaloric natural sweetener Stevioside) but not its parental compound, markedly inhibits the transport activity of OAT1 and OAT3 [46].

\section{Organic Anion transporting peptides (OATPs)}

OATPs govern cellular uptake of amphipathic molecules with molecular weights of more than $350 \mathrm{Da}$ [6]. They are widely distributed in many tissues, including the blood-brain-barrier, choroid plexus, 


\begin{tabular}{|c|c|c|c|c|c|c|}
\hline Transporter & Herbal compound & Substrate/ Inhibitor & $\begin{array}{l}\mathrm{IC}_{50} \\
(\mu \mathrm{M})\end{array}$ & $\begin{array}{c}\mathbf{K i} \\
(\mu \mathrm{M})\end{array}$ & $\begin{array}{l}\mathbf{K m} \\
(\mu \mathrm{M})\end{array}$ & Reference \\
\hline \multirow[t]{8}{*}{ OAT1 } & Baicalein & Inhibitor & $11.8 \pm 6.2$ & ND & ND & [33] \\
\hline & Wogonin & Inhibitor & $5.4 \pm 2.8$ & ND & ND & [33] \\
\hline & Rosmarinic acid & Inhibitor & ND & $0.35 \pm 0.06$ & ND & [36] \\
\hline & Aristololchic acids (AA-I) & Inhibitor & $0.44 \pm 0.08$ & $0.08 \pm 0.15$ & ND & [42] \\
\hline & Aristolochic acids (AA-II) & Inhibitor & $1.06 \pm 0.09$ & ND & ND & [42] \\
\hline & Rhein & Inhibitor & $0.0771 \pm 0.0055$ & $0.0715 \pm 0.0052$ & ND & [36] \\
\hline & Gallic acid & Inhibitor & $1.24 \pm 0.36$ & $1.08 \pm 0.26$ & ND & [37] \\
\hline & 3-monoglucuronyl-glycyrrhetinic acid & Substrate & ND & ND & 50.9 & [43] \\
\hline \multirow[t]{12}{*}{ OAT3 } & Ursolic acid & Inhibitor & $18.9 \pm 8.20$ & ND & ND & [19] \\
\hline & Baicalin & Inhibitor & $13.0 \pm 5.1$ & ND & ND & [33] \\
\hline & Baicalein & Inhibitor & $2.4 \pm 1.3$ & ND & ND & [33] \\
\hline & Wogonin & Inhibitor & $1.3 \pm 0.3$ & ND & ND & [33] \\
\hline & Rosmarinic acid & Inhibitor & ND & $0.55 \pm 0.25$ & ND & {$[36]$} \\
\hline & Lithospermic acid & Inhibitor & ND & $0.59 \pm 0.26$ & ND & [36] \\
\hline & Salvianolic acid A & Inhibitor & ND & $0.16 \pm 0.03$ & ND & {$[36]$} \\
\hline & Aristololchic acids (AA-I) & Inhibitor & $0.65 \pm 0.08$ & $0.84 \pm 0.10$ & ND & {$[42]$} \\
\hline & Aristolochic acids (AA-II) & Inhibitor & $1.28 \pm 0.18$ & ND & ND & [42] \\
\hline & Rhein & Inhibitor & $0.0084 \pm 0.0025$ & $0.0077 \pm 0.0074$ & ND & {$[36]$} \\
\hline & Gallic acid & Inhibitor & $9.02 \pm 3.24$ & $8.44 \pm 3.03$ & ND & [37] \\
\hline & 3-monoglucuronyl-glycyrrhetinic acid & Substrate & ND & ND & 21.3 & [43] \\
\hline OAT4 & Baicalin & Inhibitor & $15.6 \pm 5.50$ & ND & ND & [33] \\
\hline
\end{tabular}

ND: Not determined.

Table 2: The interactions of herbal compounds with human OATs.

intestine, kidney, placenta and testes [47]. Until now, 11 human OATP isoforms have been identified, which are divided into six subcategories (OATP1-6).

Tissue distributions: OATP1A2 is the first classic OATP membrane isolated in human with tissue localization in multiple organs [48,49]. OATP1A2 is expressed in cholangiocytes and is involved in the reabsorption of xenobiotics excreted into the bile [50]. It is also expressed at the apical membrane of the distal nephron [50], where it is responsible for the reabsorption from or the secretion of xenobiotics into the urine. OATP1B1 and OATP1B3 are liver specific OATP isoforms [51-53]. OATP2A1 is ubiquitously located throughout the body as a prostaglandin transporter [54,55]. OATP2B1 is another isoform with wide tissue distribution [56]. OATP4C1 is a renal specific isoform with high-affinities to digoxin and thyroid hormones [57]. Among all the OATPs, OATP1A2, OATP1B1, OATP1B3 and OATP2B1 are well characterized with regards to drug performance [58].

Substrate specificity: OATPs have a wide spectrum of substrates, the majority of which are large hydrophobic anions. The prototypical endogenous substrates of OATPs include bile acids, thyroid hormones, prostaglandins, eicosanoids, steroids and their conjugates [59]. For instance, OATPs mediate the hepatic uptake of microcystin, the toxin in blue-green algae that is a major water-borne pollutant in the world [60]. The classic exogenous drugs that transported through OATPs are imatinib, fexofenadine, methotrexate, HIV protease inhibitors and statins $[6,61]$.

Clinical significance: OATPs expression has been found to be altered in disease states. Previous studies have shown that mRNA expressions of OATP1A2, OATP1B1 and OATP1B3 were decreased in the liver under conditions of cholestasis [62-64]. OATP1B1 expression is reduced in patients with severe versus mild viral hepatitis [65].

Defective genes that encode variant OATPs may impair the clearance of albumin-bound bilirubin leading to severe neonatal jaundice and unconjugated hyperbilirubinemia (Gilbert's Syndrome, affecting 2-5\% of the population) [66,67]. Moreover, it has been suggested that OATP dysfunction is a significant pathological component of fibrosis [68], inflammatory bowel disease [69] and cholestasis [70].

Several genetic variants coded by OATP polymorphisms possess decreased or abolished transport function. Naturally occurring variants of OATP1A2 have been implied to influence the disposition of methotrexate, imatinib and central nervous drug entry [50,61,71]. Several single nucleotide polymorphisms of OATP1B1 have been indicated to be associated with altered pharmacokinetic performance of drugs such as pravastatin and nateglinide [72-76]. Research also demonstrated that natural mutantions in OATP2B1 gene might be important in pharmacokinetics of fexofenadine [77].

The interactions of herbal compounds with OATPs: OATP1B1, OATP1B3, OATP2B1 are in charge of the uptake of molecules into the hepatocytes to initiate the subsequent biliary excretion and/ or drug metabolism; while OATP1A2 assists in the reabsorption of clinically important and frequently prescribed drugs from the bile duct in liver. OATP1A2 is also involved in the reabsorption from or the secretion of xenobiotics into urine in the kidney and OATP2B1 facilitates the intestinal absorption of many drugs at the apical membrane of enterocytes. Therefore, these OATP isomembers are essential to drug absorption, distribution and elimination. Up to date, a wide range of herbal compounds has been shown to possess inhibitory effects on OATP-mediated uptake (Table 3). The findings have profound significance in clinical settings as to prevent drug-drug/ herb interactions through these transporters in therapies.

Our group recently reported that Baicalein and baicalin isolated from Scutellaria baicalensis have potent inhibitory effect on OATP1B3 uptake; while baicalin can also impair the substrate uptake mediated through OATP2B1 [33]. And the active components of pomegranate, 
Citation: Lu X, Chan T, Xu C, Ng WV, Zhu L (2014) The Interactions of Herbal Compounds with Human Organic Anion/Cation Transporters. J Pharmacogenomics Pharmacoproteomics 5: 142. doi:10.4172/2153-0645.1000142

Page 4 of 8

\begin{tabular}{|c|c|c|c|c|c|c|}
\hline Transporter & Herbal compound & Substrate/ Inhibitor & $\begin{array}{l}\mathbf{I C}_{50} \\
(\mu \mathrm{M})\end{array}$ & $\begin{array}{c}\mathbf{K i} \\
(\mu \mathrm{M})\end{array}$ & $\begin{array}{l}\mathbf{K m} \\
(\mu \mathrm{M})\end{array}$ & Reference \\
\hline \multirow[t]{8}{*}{ OATP2B1 } & Ursolic acid & Inhibitor & $11.0 \pm 5.0$ & ND & ND & [19] \\
\hline & Baicalin & Inhibitor & $5.6 \pm 3.2$ & ND & ND & [33] \\
\hline & Baicalein & Inhibitor & ND & ND & ND & [33] \\
\hline & Wogonin & Inhibitor & ND & ND & ND & [33] \\
\hline & Icariin & Inhibitor & $6.4 \pm 1.9$ & ND & ND & [78] \\
\hline & Silybin A & Inhibitor & 4.5 & ND & ND & [80] \\
\hline & Silybin B & Inhibitor & 0.8 & ND & ND & {$[80]$} \\
\hline & Silychristin & Inhibitor & 3.6 & ND & ND & {$[80]$} \\
\hline \multirow[t]{11}{*}{ OATP1B3 } & Gallic acid & Inhibitor & $1.6 \pm 0.6$ & ND & ND & [19] \\
\hline & Baicalin & Inhibitor & $13.7 \pm 3.6$ & ND & ND & [33] \\
\hline & Baicalein & Inhibitor & $7.7 \pm 2.4$ & ND & ND & [33] \\
\hline & Wogonin & Inhibitor & $7.7 \pm 3.1$ & ND & ND & [33] \\
\hline & Icariin & Inhibitor & $3.0 \pm 1.3$ & ND & ND & [78] \\
\hline & Silybin A & Inhibitor & 2.7 & ND & ND & [80] \\
\hline & Silybin B & Inhibitor & 5.0 & ND & ND & [80] \\
\hline & Silychristin & Inhibitor & 36.4 & ND & ND & [80] \\
\hline & Epicatechin-gallate & Substrate & ND & ND & 34.1 & [81] \\
\hline & Epigallocate-chin gallate & Substrate & ND & ND & 13.2 & [81] \\
\hline & Dioscin & Substrate & ND & ND & $2.08 \pm 0.27$ & [84] \\
\hline \multirow[t]{9}{*}{ OATP1B1 } & Baicalin & Inhibitor & $121.0 \pm 9.3$ & ND & ND & [33] \\
\hline & Baicalein & Inhibitor & $172.6 \pm 6.3$ & ND & ND & [33] \\
\hline & Wogonin & Inhibitor & $>200$ & ND & ND & [33] \\
\hline & Icariin & Inhibitor & $21.9 \pm 2.0$ & ND & ND & [23] \\
\hline & Silybin A & Inhibitor & 9.7 & ND & ND & [80] \\
\hline & Silybin B & Inhibitor & 8.5 & ND & ND & [80] \\
\hline & Silychristin & Inhibitor & 9.0 & ND & ND & [80] \\
\hline & Periplocin & Inhibitor & ND & ND & ND & [85] \\
\hline & Epigallocatechin gallate & Inhibitor & 7.8 & ND & ND & [81] \\
\hline \multirow[t]{3}{*}{ OATP1A2 } & Epicatechin gallate & Substrate & 10.2 & ND & 10.4 & [81] \\
\hline & Epigallocatechin gallate & Substrate & 54.8 & ND & 18.8 & [81] \\
\hline & Quercetin & Substrate & ND & ND & $2.3 \pm 1.5$ & [83] \\
\hline OATP4C1 & $\begin{array}{l}\text { 3-monoglucuronyl- } \\
\text { glycyrrhetinic acid }\end{array}$ & Substrate & ND & ND & 33.1 & [43] \\
\hline
\end{tabular}

ND: not determined

Table 3: The interactions of herbal compounds with human OATPs.

ursolic acid and gallic acid significantly inhibit OATP2B1 and OATP1B3 activities [19]. We also showed Icariin, a natural prenylated flavonol glycoside popularly used to treat sexual dysfunction in males and osteoporosis remarkably impairs the substrate uptake via OATP1B1, OATP1B3 and OATP2B1, which observation is consistent with the early study [78,79].

The modulated functions of OATPs have also been widely reported in a number of early studies. The flavonolignans silybin A, silybin B and silychristin isolated from hepatoprotective Silybum marianum (milk thistle) are all capable of down-regulating the activities of OATP1B1, OATP1B3 and OATP2B1 [80]. Uptake of OATP1A2, OATP1B1 and OATP2B1 could be impaired by two of the flavonols enriched in Green Tea (Camellia Simensis), epicatechin gallate (ECG) and epigallocatechin gallate (EGCG) [81]. Both flavonols were also confirmed to be substrates of OATP1A2 and OATP1B3 but not of OATP1B1 or OATP2B1 [81]. Because of the large consumption of green tea world-widely as to its reputed health benefits, such findings have profound clinically significance widely influencing pharmaceutical regimens. The wide screening of flavonoids present in Ginkgo biloba and grapefruit showed that these compounds have competitive inhibitions on substrate uptake mediated by OATP1B1 and OATP1B3 with quercetin, apigenin and naringenin being the most potent [82]. In the recent study of Glaeser et al., quercetin showed a significantly increased uptake into OATP1A2-, OATP2A1- and OATP2B1-expressing cells; while Kaempferol was not likely a substrate of all these transporter isoforms [83].

Literatures also revealed several other natural compounds impair the activities of OATP isoforms. Dioscin is a natural spirostane saponin, which can be obtained from many oriental vegetables and traditional medicinal plants with anti-hepatitis, anti-tumor and anti-fungal effects. Literature revealed that dioscin is a potent substrate of OATP1B3 with high binding affinity [84]. Periplocin is the root of Periploca sepium Bge used in ancient china for alleviating rheumatic conditions. Its tumor suppressive and anti-chronic heart failure has recently been recognized. Liang et al. implied that OATPs (OATP1A2/1B1/1B3/2B1) might be involved with the intestinal absorption and biliary excretion of such compound [85], but further studies will be required to explore the interactions of periplocin with these OATP isoforms.

Similar to the cases of OATs, metaboliste and/or derivatives of natural compounds have also been indicated to interact with OATPs, such as the liquorice metabolite 3MGA being a substrate of OATP4C1 [43].

\section{Organic Cation Transporters (OCTs)}

Besides OATs, the SLC22A gene family also encodes the Organic 


\begin{tabular}{|c|c|c|c|c|c|c|}
\hline Transporter & $\begin{array}{c}\text { Herbal } \\
\text { compound }\end{array}$ & $\begin{array}{c}\text { Substrate/ } \\
\text { Inhibitor }\end{array}$ & $\begin{array}{c}\mathbf{I C}_{50} \\
(\mu \mathrm{M})\end{array}$ & $\begin{array}{c}\mathbf{K i} \\
(\mu \mathrm{M})\end{array}$ & $\begin{array}{c}\mathbf{K m} \\
(\mu \mathrm{M})\end{array}$ & Reference \\
\hline OCT1 & Quercetin & Substrate & $\mathrm{ND}$ & $\mathrm{ND}$ & $2.2 \pm 0.2$ & {$[83]$} \\
\hline OCT3 & Wogonin & Inhibitor & $3.7 \pm 1.3$ & $\mathrm{ND}$ & $\mathrm{ND}$ & {$[33]$} \\
\hline
\end{tabular}

ND: not determined

Table 4: The interactions of herbal compounds with human OCTs.

cation transporters (OCT1, OCT2 and OCT3) as well as the organic cation/carnitine transporters (OCTN1 and OCTN2). Like other SLC transporters, OCTs and OCTNs are also responsible for the uptake of numerous endogenous and exogenous substrates [6].

Tissue distribution: In common, OCT1, OCT2 and OCT3 are expressed in a variety of tissues such as the intestines, placenta and lung. OCT1 is mainly expressed at the basolateral membrane of hepatocytes [86]; while OCT2 protein is localized to the apical membrane of the distal convoluted tubules [87]. OCT3 is abundantly distributed in brain tissues. OCTN1 and OCTN2 have their tissue localization to the heart, placenta, skeletal muscle, kidney and pancreas [6].

Substrate specificity: OCTs facilitate the movement of small cationic molecules including catecholamines, monoamine neurotransmitters, 1-methyl-4-phenylpridinium $\left(\mathrm{MPP}^{+}\right)$and about half of the therapeutic agents used in human like tetraethylammonium (TEA) [6]. OCTN1 and OCTN2 have extensive physiological roles in mediating bidirectional movements of important endogenous substrates, eg. both OCTN1 and OCTN2 are involved in the transport of carnitine and OCTN1 also facilitates the uptake of acetylcholine [8890]. TEA is the common drug substrate of both OCTN1 and OCTN2; while the mushroom metabolite L-ergothioneine is a specific substrate of OCTN1 [91-93].

Clinical significance: OCT1 have been extensively studied for their associations with the pharmacokinetics of anti-diabetic drug metformin as well as the pharmacological responses of front-line anticancer agent imatinib [94-107]. OCT2 has also been implicated in pharmacokinetics of various drugs [108-111].

Deficiency of the diet component L-carnitine leads to immunosuppression and intestinal inflammation. Since L-carnitine is a shared substrate of OCTN1 and OCTN2, genetic polymorphisms of OCTN1 and OCTN2 have been intensively explored for their associations with many common gastrointestinal disorders such as inflammatory bowel disease, colorectal cancer and Crohn's disease [112-115]. Additionally they have also been implicated in other prevalent diseases like rheumatoid arthritis [116-119].

The interactions of herbal compounds with OCTs and OCTNs: Limited information is available with the influence of natural compounds on the transport activity of OCTs and OCTNs. OCT3 activity can be down-regulated in the presences of wogonin [33]. And quercetin is a substrate of OCT1; while its structurally similar flavonoid kaempferol is not a substrate of OCT1 [83] (Table 4). As mentioned above, the essential dietary component L-carnine can be transported by both OCTN1 and OCTN2 [89,90]; while L-ergothioneine enriched in mushrooms selectively interact with OCTN1 [91-93].

\section{Perspectives}

Consumption of herbal products continuously increases in the world due to their reputed health benefits. They are often considered as supplementary and/or alternative to conventional therapies. In recent years, co-administration of drugs with herbal remedies widely raises concerns due to numerous cases of drug-herb interactions. Therefore it is essential to review potential drug-drug/herb interactions as well as the underneath molecular mechanisms so as to prevent serious adverse effects in therapies.

SLC transporters especially OATs, OATPs and OCTs are widely expressed throughout the body and responsible for the cellular influx of many endogenous and exogenous substrates including numerous clinically important drugs and natural compounds. Drug-drug/herb interactions often occur when drugs competing specific transporter proteins with other drugs or herbal compounds. Limited knowledge about these transporter-mediated substrate interactions largely impedes the therapeutic optimization to avoid unfavorable adverse events. Studies to elucidate the influence of herbal preparations (as mixtures) on drug performance are not sufficient to reveal the problematic components leading to side effects, which then restrict the clinical applications of many herbal medicines. Therefore, exploring the interactions of individual herbal compounds with specific transporters should be warranted in order to serve better in developing safer and more efficient treatment strategies. Considering herbal products often have multiple constituents, the potential cumulative influence of herbal compounds on drug performance mediated through transporters could then be developed so as to better predict therapeutic outcomes in patients.

\section{Disclosure statement}

The authors claim no conflict of interests.

\section{References}

1. Zhou F, You G (2007) Molecular insights into the structure-function relationship of organic anion transporters OATs. Pharm Res 24: 28-36.

2. Kim RB (2003) Organic anion-transporting polypeptide (OATP) transporter family and drug disposition. Eur J Clin Invest 33 Suppl 2: 1-5.

3. Motohashi $\mathrm{H}$, Inui K (2013) Organic cation transporter OCTs (SLC22) and MATEs (SLC47) in the human kidney. AAPS J 15: 581-588.

4. Shitara Y, Maeda K, Ikejiri K, Yoshida K, Horie T, et al. (2013) Clinical significance of organic anion transporting polypeptides (OATPs) in drug disposition: their roles in hepatic clearance and intestinal absorption. Biopharm Drug Dispos 34: 45-78.

5. Im-Sook Song, Tae Yeon Kong, Hyeon-Uk Jeong, Eun Nam Kim, Soon-Sang Kwon, et al. (2014) Evaluation of the transporter-mediated herb-drug interaction potential of DA-9801, a standardized dioscorea extract for diabetic neuropathy, in human in vitro and rat in vivo. BMC Complement Altern Med 14: 251.

6. Roth M, Obaidat A, Hagenbuch B (2012) OATPs, OATs and OCTs: the organic anion and cation transporters of the SLCO and SLC22A gene superfamilies. Br J Pharmacol 165: 1260-1287.

7. Wolff NA, Werner A, Burkhardt S, Burckhardt G (1997) Expression cloning and characterization of a renal organic anion transporter from winter flounder FEBS Lett 417: 287-291.

8. Sekine T, Watanabe N, Hosoyamada M, Kanai Y, Endou H (1997) Expression cloning and characterization of a novel multispecific organic anion transporter. J Biol Chem 272: 18526-18529.

9. Sweet DH, Wolff NA, Pritchard JB (1997) Expression cloning and characterization of ROAT1. The basolateral organic anion transporter in rat kidney. J Biol Chem 272: 30088-30095

10. Tanaka K, Xu W, Zhou F, You G (2004) Role of glycosylation in the organic anion transporter OAT1. J Biol Chem 279: 14961-14966.

11. Hong M, Zhou F, You G (2004) Critical amino acid residues in transmembrane domain 1 of the human organic anion transporter hOAT1. J Biol Chem 279: 31478-31482.

12. Zhou F, Tanaka K, Pan Z, Ma J, You G (2004) The role of glycine residues in the function of human organic anion transporter 4. Mol Pharmacol 65: 1141-1147.

13. Hong M, Xu W, Yoshida T, Tanaka K, Wolff DJ, et al. (2005) Human organic anion transporter hOAT1 forms homooligomers. J Biol Chem 280: 32285-32290. 
Citation: Lu X, Chan T, Xu C, Ng WV, Zhu L (2014) The Interactions of Herbal Compounds with Human Organic Anion/Cation Transporters. J Pharmacogenomics Pharmacoproteomics 5: 142. doi:10.4172/2153-0645.1000142

14. Hong M, Zhou F, Lee K, You G (2007) The putative transmembrane segment 7 of human organic anion transporter hOAT1 dictates transporter substrate binding and stability. J Pharmacol Exp Ther 320: 1209-1215.

15. Hong M, Li S, Zhou F, Thomas PE, You G (2010) Putative transmembrane domain 12 of the human organic anion transporter hOAT1 determines transporter stability and maturation efficiency. J Pharmacol Exp Ther 332: 650-658.

16. Cheng Y, Vapurcuyan A, Shahidullah M, Aleksunes LM, Pelis RM (2012) Expression of organic anion transporter 2 in the human kidney and its potential role in the tubular secretion of guanine-containing antiviral drugs. Drug Metab Dispos 40: 617-624.

17. Sekine T, Cha SH, Tsuda M, Apiwattanakul N, Nakajima N, et al. (1998) Identification of multispecific organic anion transporter 2 expressed predominantly in the liver. FEBS Lett 429: 179-182.

18. Kusuhara H, Sekine T, Utsunomiya-Tate N, Tsuda M, Kojima R, et al. (1999) Molecular cloning and characterization of a new multispecific organic anion transporter from rat brain. J Biol Chem 274: 13675-13680.

19. Li Z, Wang K, Zheng J, Cheung FS, Chan T, et al. (2014) Interactions of the active components of Punica granatum (pomegranate) with the essential renal and hepatic human Solute Carrier transporters. Pharm Biol 52: 1510-1517.

20. Zhou F, Xu W, Tanaka K, You G (2008) Comparison of the interaction of human organic anion transporter hOAT4 with PDZ proteins between kidney cells and placental cells. Pharm Res 25: 475-480.

21. Zhou F, Hong M, You G (2007) Regulation of human organic anion transporte 4 by progesterone and protein kinase $C$ in human placental BeWo cells. Am J Physiol Endocrinol Metab 293: E57-61.

22. Zhou F, Pan Z, Ma J, You G (2004) Mutational analysis of histidine residues in human organic anion transporter 4 (hOAT4). Biochem J 384: 87-92.

23. Shin HJ, Anzai N, Enomoto A, He X, Kim do K, et al. (2007) Novel liverspecific organic anion transporter OAT7 that operates the exchange of sulfate conjugates for short chain fatty acid butyrate. Hepatology 45: 1046-1055.

24. Sun W, Wu RR, van Poelje PD, Erion MD (2001) Isolation of a family of organic anion transporters from human liver and kidney. Biochem Biophys Res Commun 283: 417-422.

25. Bahn A, Hagos Y, Reuter S, Balen D, Brzica H, et al. (2008) Identification of a new urate and high affinity nicotinate transporter, hOAT10 (SLC22A13). J Biol Chem 283: 16332-16341

26. Cihlar T, Lin DC, Pritchard JB, Fuller MD, Mendel DB, et al. (1999) The antivira nucleotide analogs cidofovir and adefovir are novel substrates for human and rat renal organic anion transporter 1. Mol Pharmacol 56: 570-580.

27. Hosoyamada M, Sekine T, Kanai Y, Endou H (1999) Molecular cloning and functional expression of a multispecific organic anion transporter from human kidney. Am J Physiol 276: F122-128.

28. Cha SH, Sekine T, Fukushima JI, Kanai Y, Kobayashi Y, et al. (2001) Identification and characterization of human organic anion transporter 3 expressing predominantly in the kidney. Mol Pharmacol 59: 1277-1286.

29. Nigam SK, Bush KT, Bhatnagar V (2007) Drug and toxicant handling by the OAT organic anion transporters in the kidney and other tissues. Nat Clin Pract Nephrol 3: 443-448.

30. Aherne GW, Piall E, Marks V, Mould G, White WF (1978) Prolongation and enhancement of serum methotrexate concentrations by probenecid. Br Med J 1: 1097-1099.

31. Aherne W, Piall E, Marks V (1978) Radioimmunoassay of methotrexate: use of 75Se-labelled methotrexate. Ann Clin Biochem 15: 331-334.

32. Nozaki Y, Kusuhara H, Kondo T, Iwaki M, Shiroyanagi Y, et al. (2007) Species difference in the inhibitory effect of nonsteroidal anti-inflammatory drugs on the uptake of methotrexate by human kidney slices. J Pharmacol Exp Ther 322: 1162-1170.

33. Xu, F, Li Z, Zheng J, Cheung FSG, Chan T, et al. (2013) The inhibitory effects of the bioactive components isolated from Scutellaria baicalensis on the cellular uptake mediated by the essential solute carrier transporters. J Pharm Sci 102 : 4205-4211.

34. Shang X, He X, He X, Li M, Zhang R, et al. (2010) The genus Scutellaria an ethnopharmacological and phytochemical review. J Ethnopharmacol 128: 279-313.
35. Wang L, Venitz J, Sweet DH (2014) Cumulative organic anion transportermediated drug-drug interaction potential of multiple components in salvia miltiorrhiza (danshen) preparations. Pharm Res 31: 3503-3514.

36. Wang L, Pan X, Sweet DH (2013) The anthraquinone drug rhein potently interferes with organic anion transporter-mediated renal elimination. Biochem Pharmacol 86: 991-996.

37. Wang L, Sweet $\mathrm{DH}$ (2012) Potential for food-drug interactions by dietary phenolic acids on human organic anion transporters 1 (SLC22A6), 3 (SLC22A8), and 4 (SLC22A11). Biochem Pharmacol 84: 1088-1095.

38. Hong SS, Seo K, Lim SC, Han HK (2007) Interaction characteristics of flavonoids with human organic anion transporter 1 (hOAT1) and 3 (hOAT3). Pharmacol Res 56: 468-473.

39. Parkin DM (2004) International variation. Oncogene 23: 6329-6340.

40. Parkin DM, Pisani P, Ferlay J (1993) Estimates of the worldwide incidence of eighteen major cancers in 1985. Int J Cancer 54: 594-606.

41. Blot WJ, Devesa SS, Kneller RW, Fraumeni JF Jr (1991) Rising incidence of adenocarcinoma of the esophagus and gastric cardia. JAMA 265: 1287-1289.

42. Babu E, Takeda M, Nishida R, Noshiro-Kofuji R, Yoshida M, et al. (2010) Interactions of human organic anion transporters with aristolochic acids. J Pharmacol Sci 113: 192-196.

43. Makino T (2014) 3-Monoglucuronyl glycyrrhretinic acid is a possible marke compound related to licorice-induced pseudoaldosteronism. Biol Pharm Bull 37: 898-902.

44. Arase Y, Ikeda K, Murashima N, Chayama K, Tsubota A, et al. (1997) The long term efficacy of glycyrrhizin in chronic hepatitis $\mathrm{C}$ patients. Cancer 79 1494-1500.

45. Kumada $\mathrm{H}$ (2002) Long-term treatment of chronic hepatitis $\mathrm{C}$ with glycyrrhizin [stronger neo-minophagen $\mathrm{C}(\mathrm{SNMC})$ ] for preventing liver cirrhosis and hepatocellular carcinoma. Oncology 62 Suppl 1: 94-100.

46. Srimaroeng C, Chatsudthipong V, Aslamkhan AG, Pritchard JB (2005) Transport of the natural sweetener stevioside and its aglycone steviol by human organic anion transporter (hOAT1; SLC22A6) and hOAT3 (SLC22A8) J Pharmacol Exp Ther 313: 621-628.

47. Hagenbuch B, Meier PJ (2004) Organic anion transporting polypeptides of the OATP/ SLC21 family: phylogenetic classification as OATP/ SLCO superfamily new nomenclature and molecular/functional properties. Pflugers Arch 447 653-665.

48. Kullak-Ublick GA, Hagenbuch B, Stieger B, Schteingart CD, Hofmann AF, et al (1995) Molecular and functional characterization of an organic anion transporting polypeptide cloned from human liver. Gastroenterology 109: 1274-1282.

49. Steckelbroeck S, Nassen A, Ugele B, Ludwig M, Watzka M, et al. (2004) Steroid sulfatase (STS) expression in the human temporal lobe: enzyme activity, mRNA expression and immunohistochemistry study. J Neurochem 89: 403-417.

50. Lee W, Glaeser H, Smith LH, Roberts RL, Moeckel GW, et al. (2005) Polymorphisms in human organic anion-transporting polypeptide $1 \mathrm{~A} 2$ (OATP1A2): implications for altered drug disposition and central nervous system drug entry. J Biol Chem 280: 9610-9617.

51. Abe T, Kakyo M, Tokui T, Nakagomi R, Nishio T, et al. (1999) Identification of a novel gene family encoding human liver-specific organic anion transporter LST-1. J Biol Chem 274: 17159-17163.

52. Hsiang B, Zhu Y, Wang Z, Wu Y, Sasseville V, et al. (1999) A novel human hepatic organic anion transporting polypeptide (OATP2). Identification of a liver-specific human organic anion transporting polypeptide and identification of rat and human hydroxymethylglutaryl-CoA reductase inhibitor transporters. $J$ Biol Chem 274: 37161-37168.

53. König J, Cui Y, Nies AT, Keppler D (2000) Localization and genomic organization of a new hepatocellular organic anion transporting polypeptide. $\mathrm{J}$ Biol Chem 275: 23161-23168.

54. Nomura T, Lu R, Pucci ML, Schuster VL (2004) The two-step model of prostaglandin signal termination: in vitro reconstitution with the prostaglandin transporter and prostaglandin 15 dehydrogenase. Mol Pharmacol 65: 973-978.

55. Nomura T, Chang HY, Lu R, Hankin J, Murphy RC, et al. (2005) Prostaglandin signaling in the renal collecting duct: release, reuptake, and oxidation in the same cell. J Biol Chem 280: 28424-28429. 
Citation: Lu X, Chan T, Xu C, Ng WV, Zhu L (2014) The Interactions of Herbal Compounds with Human Organic Anion/Cation Transporters. J Pharmacogenomics Pharmacoproteomics 5: 142. doi:10.4172/2153-0645.1000142

Page 7 of 8

56. Tamai I, Nezu J, Uchino H, Sai Y, Oku A et al. (2000) Molecular identification and characterization of novel members of the human organic anion transporter (OATP) family. Biochem Biophys Res Commun 273: 251-260.

57. Yamaguchi H, Sugie M, Okada M, Mikkaichi T, Toyohara T, et al. (2010) Transport of estrone 3-sulfate mediated by organic anion transporter OATP4C1: estrone 3-sulfate binds to the different recognition site for digoxin in OATP4C1. Drug Metab Pharmacokinet 25: 314-317.

58. Hagenbuch B, Gui C (2008) Xenobiotic transporters of the human organic anion transporting polypeptides (OATP) family. Xenobiotica 38: 778-801.

59. Clarke JD, Cherrington NJ (2012) Genetics or environment in drug transport: the case of organic anion transporting polypeptides and adverse drug reactions. Expert Opin Drug Metab Toxicol 8: 349-360.

60. Fischer WJ, Altheimer S, Cattori V, Meier PJ, Dietrich DR, et al. (2005) Organic anion transporting polypeptides expressed in liver and brain mediate uptake of microcystin. Toxicol Appl Pharmacol 203: 257-263.

61. Zhou F, Zheng J, Zhu L, Jodal A, Cui PH, et al. (2013) Functional analysis of novel polymorphisms in the human SLCO1A2 gene that encodes the transporter OATP1A2. AAPS J 15: 1099-1108.

62. Keitel V, Burdelski M, Warskulat U, Kühlkamp T, Keppler D, et al. (2005) Expression and localization of hepatobiliary transport proteins in progressive familial intrahepatic cholestasis. Hepatology 41: 1160-1172.

63. Chen HL, Liu YJ, Chen HL, Wu SH, Ni YH, et al. (2008) Expression of hepatocyte transporters and nuclear receptors in children with early and latestage biliary atresia. Pediatr Res 63: 667-673.

64. Congiu M, Mashford ML, Slavin JL, Desmond PV (2009) Coordinate regulation of metabolic enzymes and transporters by nuclear transcription factors in human liver disease. J Gastroenterol Hepatol 24: 1038-1044.

65. Oswald M, Kullak-Ublick GA, Paumgartner G, Beuers U (2001) Expression of hepatic transporters OATP-C and MRP2 in primary sclerosing cholangitis. Liver 21: $247-253$

66. Campbell SD, de Morais SM, Xu JJ (2004) Inhibition of human organic anion transporting polypeptide OATP 1B1 as a mechanism of drug-induced hyperbilirubinemia. Chem Biol Interact 150: 179-187.

67. Cui Y, König J, Leier I, Buchholz U, Keppler D (2001) Hepatic uptake of bilirubin and its conjugates by the human organic anion transporter SLC21A6. J Biol Chem 276: 9626-9630.

68. Nakai K, Tanaka H, Hanada K, Ogata H, Suzuki F, et al. (2008) Decreased expression of cytochromes P450 1A2, 2E, and $3 \mathrm{~A} 4$ and drug transporters $\mathrm{Na}$--taurocholate-cotransporting polypeptide, organic cation transporter, and organic anion-transporting peptide-C correlates with the progression of liver fibrosis in chronic hepatitis C patients. Drug Metab Dispos 36: 1786-1793.

69. Wojtal KA, Eloranta JJ, Hruz P, Gutmann H, Drewe J, et al. (2009) Changes in mRNA expression levels of solute carrier transporters in inflammatory bowel disease patients. Drug Metab Dispos 37: 1871-1877.

70. Brandoni A, Torres A.M (2009) Characterization of the mechanisms involved in the increased renal elimination of bromosulfophthalein during cholestasis: involvement of Oatp1. J Histochem Cytochem 57: 449-456.

71. Yamakawa Y, Hamada A, Shuto T, Yuki M, Uchida T, et al. (2011) Pharmacokinetic impact of SLCO1A2 polymorphisms on imatinib disposition in patients with chronic myeloid leukemia. Clin Pharmacol Ther 90: 157-163.

72. Nishizato Y, leiri I, Suzuki H, Kimura M, Kawabata K, et al. (2003) Polymorphisms of OATP-C (SLC21A6) and OAT3 (SLC22A8) genes: consequences for pravastatin pharmacokinetics. Clin Pharmacol Ther 73: 554-565.

73. Chung JY, Cho JY, Yu KS, Kim JR, Oh DS, et al. (2005) Effect of OATP1B1 (SLCO1B1) variant alleles on the pharmacokinetics of pitavastatin in healthy volunteers. Clin Pharmacol Ther 78: 342-350.

74. Wen J, Xiong Y (2010) OATP1B1 388A>G polymorphism and pharmacokinetics of pitavastatin in Chinese healthy volunteers. J Clin Pharm Ther 35: 99-104.

75. Mwinyi J, Johne A, Bauer S, Roots I, Gerloff T (2004) Evidence for inverse effects of OATP-C (SLC21A6) 5 and $1 \mathrm{~b}$ haplotypes on pravastatin kinetics. Clin Pharmacol Ther 75: 415-421.

76. Zhang W, He YJ, Han CT, Liu ZQ, Li Q, et al. (2006) Effect of SLCO1B1 genetic polymorphism on the pharmacokinetics of nateglinide. Br J Clin Pharmacol 62: 567-572.
77. Akamine $Y$, Miura M, Sunagawa S, Kagaya H, Yasui-Furukori N, et al. (2010) Influence of drug-transporter polymorphisms on the pharmacokinetics of fexofenadine enantiomers. Xenobiotica 40: 782-789.

78. Li Z, Cheung FS, Zheng J, Chan T, Zhu L, et al. (2014) Interaction of the bioactive flavonol, icariin, with the essential human solute carrier transporters. J Biochem Mol Toxicol 28: 91-97.

79. Wu LX, Guo CX, Qu Q, Yu J, Chen WQ, et al. (2012) Effects of natura products on the function of human organic anion transporting polypeptide 1B1. Xenobiotica 42: 339-348.

80. Köck K, Xie Y, Hawke RL, Oberlies NH, Brouwer KL (2013) Interaction of silymarin flavonolignans with organic anion-transporting polypeptides. Drug Metab Dispos 41: 958-965.

81. Roth M, Timmermann BN, Hagenbuch B (2011) Interactions of green tea catechins with organic anion-transporting polypeptides. Drug Metab Dispos 39: 920-926.

82. Mandery K, Balk B, Bujok K, Schmidt I, Fromm MF, et al. (2012) Inhibition of hepatic uptake transporters by flavonoids. Eur J Pharm Sci 46: 79-85.

83. Glaeser H, Bujok K, Schmidt I, Fromm MF, Mandery K (2014) Organic anion transporting polypeptides and organic cation transporter 1 contribute to the cellular uptake of the flavonoid quercetin. Naunyn Schmiedebergs Arch Pharmacol 387: 883-891.

84. Zhang A, Wang C, Liu Q, Meng Q, Peng J, et al. (2013) Involvement of organic anion-transporting polypeptides in the hepatic uptake of dioscin in rats and humans. Drug Metab Dispos 41: 994-1003.

85. Liang S, Deng F, Xing H, Wen H, Shi X, et al. (2014) P-glycoprotein- and organic anion-transporting polypeptide-mediated transport of periplocin may lead to drug-herb/drug-drug interactions. Drug Des Devel Ther 8: 475-483.

86. Nies AT, Herrmann E, Brom M, Keppler D (2008) Vectorial transport of the plant alkaloid berberine by double-transfected cells expressing the human organic cation transporter 1 (OCT, SLC22A1) and the efflux pump MDR1 P-glycoprotein (ABCB1). Naunyn Schmiedebergs Arch Pharmacol 376: 449-461.

87. Gorboulev V, Ulzheimer JC, Akhoundova A, Ulzheimer-Teuber I, Karbach U et al. (1997) Cloning and characterization of two human polyspecific organic cation transporters. DNA Cell Biol 16: 871-881.

88. Pochini L, Scalise M, Galluccio M, Pani G, Siminovitch KA, et al. (2012) The human OCTN1 (SLC22A4) reconstituted in liposomes catalyzes acetylcholine transport which is defective in the mutant L503F associated to the Crohn's disease. Biochim Biophys Acta 1818: 559-565.

89. Tamai I, Nakanishi T, Kobayashi D, China K, Kosugi Y, et al. (2004) Involvement of OCTN1 (SLC22A4) in pH-dependent transport of organic cations. Mol Pharm 1: $57-66$.

90. Tamai I, Yabuuchi H, Nezu J, Sai Y, Oku A, et al. (1997) Cloning and characterization of a novel human $\mathrm{pH}$-dependent organic cation transporter, OCTN1. FEBS Lett 419: 107-111.

91. Gründemann D, Harlfinger S, Golz S, Geerts A, Lazar A, et al. (2005) Discovery of the ergothioneine transporter. Proc Natl Acad Sci U S A 102: 5256-5261.

92. Toh DS, Limenta LM, Yee JY, Wang LZ, Goh BC, et al. (2014) Effect of mushroom diet on pharmacokinetics of gabapentin in healthy Chinese subjects. Br J Clin Pharmacol 78: 129-134.

93. Toh DS, Cheung FS, Murray M, Pern TK, Lee EJ, et al. (2013) Functional analysis of novel variants in the organic cation/ergothioneine transporter 1 identified in Singapore populations. Mol Pharm 10: 2509-2516.

94. Tzvetkov MV, Seitz T, Bokelmann K, Mueller T, Brockmöller J, et al. (2014) Does the haplotype Met408-Del420, which was apparently predictive for imatinib efficacy, really exist and how strongly may it affect OCT1 activity? Blood 123: 1427-1429.

95. Nies AT, Schaeffeler E, van der Kuip H, Cascorbi I, Bruhn O, et al. (2014) Cellular uptake of imatinib into leukemic cells is independent of human organic cation transporter 1 (OCT1). Clin Cancer Res 20: 985-994.

96. Koren-Michowitz M, Buzaglo Z, Ribakovsky E, Schwarz M, Pessach I, et al. (2014) OCT1 genetic variants are associated with long term outcomes in imatinib treated chronic myeloid leukemia patients. Eur J Haematol 92: 283-288.

97. Burger H, Mathijssen RH, Sparreboom A, Wiemer EA (2013) Can "specific" OCT1 inhibitors be used to determine OCT1 transporter activity toward imatinib? Blood 121: 4965-4966. 
Citation: Lu X, Chan T, Xu C, Ng WV, Zhu L (2014) The Interactions of Herbal Compounds with Human Organic Anion/Cation Transporters. J Pharmacogenomics Pharmacoproteomics 5: 142. doi:10.4172/2153-0645.1000142

Page 8 of 8

98. Zach O, Krieger O, Foedermayr M, Zellhofer B, Lutz D (2008) OCT1 (SLC22A1) R61C polymorphism and response to imatinib treatment in chronic myeloid leukemia patients. Leuk Lymphoma 49: 2222-2223.

99. Hu S, Franke RM, Filipski KK, Hu C, Orwick SJ, et al. (2008) Interaction of imatinib with human organic ion carriers. Clin Cancer Res 14: 3141-3148.

100. Chen L, Shu Y, Liang X, Chen EC, Yee SW, et al. (2014) OCT1 is a highcapacity thiamine transporter that regulates hepatic steatosis and is a target of metformin. Proc Natl Acad Sci U S A 111: 9983-9988.

101. Tarasova L, Kalnina I, Geldnere K, Bumbure A, Ritenberga R, et al. (2012) Association of genetic variation in the organic cation transporters OCT OCT2 and multidrug and toxin extrusion 1 transporter protein genes with the gastrointestinal side effects and lower BMI in metformin-treated type 2 diabetes patients. Pharmacogenet Genomics 22: 659-666.

102. Moreno-Navarrete JM, Ortega FJ, Rodríguez-Hermosa JI, Sabater M, Pardo $\mathrm{G}$, et al. (2011) OCT1 Expression in adipocytes could contribute to increased metformin action in obese subjects. Diabetes 60: 168-176.

103. Ahlin G, Chen L, Lazorova L, Chen Y, lanculescu AG, et al. (2011) Genotypedependent effects of inhibitors of the organic cation transporter, OCT1: predictions of metformin interactions. Pharmacogenomics J 11: 400-411.

104. Becker ML, Visser LE, van Schaik RH, Hofman A, Uitterlinden AG, et al (2010) Interaction between polymorphisms in the OCT1 and MATE1 transporter and metformin response. Pharmacogenet Genomics 20: 38-44.

105. Tzvetkov MV, Vormfelde SV, Balen D, Meineke I, Schmidt T, et al. (2009) The effects of genetic polymorphisms in the organic cation transporters OCT, OCT2, and OCT3 on the renal clearance of metformin. Clin Pharmacol Ther 86: 299-306.

106. Shu Y, Brown C, Castro RA, Shi RJ, Lin ET, et al. (2008) Effect of genetic variation in the organic cation transporter, OCT, on metformin pharmacokinetics. Clin Pharmacol Ther 83: 273-280.

107. Shikata E, Yamamoto R, Takane H, Shigemasa C, Ikeda T, et al. (2007) Human organic cation transporter (OCT1 and OCT2) gene polymorphisms and therapeutic effects of metformin. J Hum Genet 52: 117-122.

108. Li J, Kim S, Sha X, Wiegand R, Wu J, et al. (2014) Complex disease-, geneand drug-drug interactions: impacts of renal function, CYP2D6 phenotype, and OCT2 activity on veliparib pharmacokinetics. Clin Cancer Res 20: 3931-3944.

109. Dumitras S, Sechaud R, Drollmann A, Pal P, Vaidyanathan S, et al. (2013) Effect of cimetidine, a model drug for inhibition of the organic cation transport
(OCT2/MATE1) in the kidney, on the pharmacokinetics of glycopyrronium. In J Clin Pharmacol Ther 51: 771-779.

110. Choi Cl, Bae JW, Keum SK, Lee YJ, Lee HI, et al. (2013) Effects of OCT2 c.602C > T genetic variant on the pharmacokinetics of lamivudine. Xenobiotica 43: 636-640.

111. Higgins JW, Bedwell DW, Zamek-Gliszczynski MJ (2012) Ablation of both organic cation transporter (OCT)1 and OCT2 alters metformin pharmacokinetics but has no effect on tissue drug exposure and pharmacodynamics. Drug Metab Dispos 40: 1170-1177.

112. Fortin G, Yurchenko K, Collette C, Rubio M, Villani AC, et al. (2009) L-carnitine a diet component and organic cation transporter OCTN ligand, displays immunosuppressive properties and abrogates intestinal inflammation. Clin Exp Immunol 156: 161-171.

113. Lin Z, Nelson L, Franke A, Poritz L, Li TY, et al. (2010) OCTN1 variant L503F is associated with familial and sporadic inflammatory bowel disease. $J$ Crohns Colitis 4: 132-138.

114. Russell RK, Drummond HE, Nimmo ER, Anderson NH, Noble CL, et at. (2006) Analysis of the influence of OCTN1/2 variants within the IBD5 locus on disease susceptibility and growth indices in early onset inflammatory bowe disease. Gut 55: 1114-1123.

115. Martini M, Ferrara AM, Giachelia M, Panieri E, Siminovitch K, et al. (2012) Association of the OCTN1/1672T variant with increased risk for colorectal cancer in young individuals and ulcerative colitis patients. Inflamm Bowel Dis 18: $439-448$.

116. Klein M, Mann H, PleÅtilovÃ $i$ L, Betteridge Z, McHugh N, et al. (2014) Arthritis in idiopathic inflammatory myopathy: clinical features and autoantibody associations. J Rheumatol 41: 1133-1139.

117. Ren TL, Han ZJ, Yang CJ, Hang YX, Fang DY, et al. (2014) Association of SLC22A4 gene polymorphism with Rheumatoid arthritis in the Chinese population. J Biochem Mol Toxicol 28: 206-210.

118. Takata $Y$, Inoue $H$, Sato A, Tsugawa K, Miyatake K, et al. (2008) Replication of reported genetic associations of PADI4, FCRL3, SLC22A4 and RUNX1 genes with rheumatoid arthritis: results of an independent Japanese population and evidence from meta-analysis of East Asian studies. J Hum Genet 53: 163-173.

119. Okada Y, Mori M, Yamada R, Suzuki A, Kobayashi K, et al. (2008) SLC22A4 polymorphism and rheumatoid arthritis susceptibility: a replication study in a Japanese population and a metaanalysis. J Rheumatol 35: 1723-1728. 